\title{
Determinants of Destination Knowledge Acquisition in Religious Tourism: Perspective of Umrah Travelers
}

\author{
Siti Hasnah Hassan ${ }^{1}$, Siti Rohaida Mohamed Zainal ${ }^{1} \&$ Osman Mohamed $^{2}$ \\ ${ }^{1}$ School of Management, Universiti Sains Malaysia, Penang, Malaysia \\ ${ }^{2}$ Graduate School of Management, Multimedia University, Cyberjaya Campus, Malaysia \\ Correspondence: Siti Hasnah Hassan, School of Management, Universiti Sains Malaysia, 11800 Penang, \\ Malaysia. Tel: 1-604-653-5165. E-mail: siti.hassan@usm.my
}

Received: March 2, $2015 \quad$ Accepted: April 2, $2015 \quad$ Online Published: May 31, 2015

doi:10.5539/ijms.v7n3p84

URL: http://dx.doi.org/10.5539/ijms.v7n3p84

\begin{abstract}
Religious travel has grown consistently with the growth of the tourism industry worldwide. However, some of the religious based tourism particularly pilgrimage tourism such as Umrah received little attention in the literature although there are 6 million people performing it each year. Thus, this study aims to examine the relationship between the factors influencing information acquisition behavior to gain destination product knowledge in performing Umrah. Survey data from 198 Umrah travelers were analyzed using Partial least squares (PLS) structural equation. The final useful sample consisted of 198 Muslim participants who had travelled to Mecca for Umrah in the last 12 months. Partial least squares (PLS) structural equation was used in data analysis. The results show that the determinants of information search, the purpose of travelling, past experience, quality of information and travel companion affect information acquisition behavior and destination product knowledge. The findings of this study will aid tour operators and travel agents in developing relevant strategies for future business development.
\end{abstract}

Keywords: destination product knowledge, information acquisition behaviour, information search, information sources, religious tourism, Umrah performers

\section{Introduction}

Religious travel has grown consistently with the growth of the tourism industry worldwide. Indeed the industry and its "associated practices interact with religious life and the institutions of religion in virtually every corner of the world" (Bremer, 2005). Due to the globalization process, factors that influence travel, such as travelling cost and ease of the travelling process, have resulted in a significant increase in the number of religious and spiritually motivated travelers. As such, religious tourism is now an important segment of international tourism and in the last five years it has developed into a full-fledged industry, this trend is expected to increase significantly in the near future (Ward, 2012, December 18).

The religious and spiritual journeys in Islam can be divided into three forms of activity (Haq \& Wong, 2010; Timothy \& Olsen, 2006). The first activity is performing Hajj, which constitutes one of the five pillars of Islam and is fundamental to Muslim practice. It is mandatory for all Muslims to visit Mecca during the specific time frame from the 8th to $12^{\text {th }}$ Dhu al-Hijjah. The second spiritual journey is Rihla, the journey in search of knowledge, commerce, health or research. The third activity is called Ziyara, which requires a Muslim to visit the shrines, mosques, or monasteries for spiritual growth (Timothy \& Olsen, 2006). A journey to fulfil the requirement for Rihlaor Ziyara, with the purpose of spiritual growth and connection with the Creator is considered to be spiritual tourism (Haq \& Wong, 2010).

Umrah is a non-compulsory pilgrimage to Mecca that can be performed by Muslims throughout the year. Unlike Haj, which is a compulsory pilgrimage for Muslims that can only be performed during a specific month and according to the Islamic calendar. Haj visas are issued by the Kingdom of Saudi Arabia based on a country by country quota. The quota system restricts the number of people able to perform Hajj in a given year with the result that some people may opt for Umrah. Umrah can be performed once or repeatedly depending on the individuals' physical and financial ability. Umrah is essentially a series of Islamic rituals that take a few hours to complete. Each trip to Mecca for Umrah normally covers ziarah (visit) to other sacred sites such as JabalTsur, 
Arafah, JabalRahmah and JabalNur Mountain in Mecca and also sacred places in Medina. According to Ali Mohammed Al-Ghamdi, the spokesperson from the Ministry of Hajj from the Kingdom of Saudi Arabia, the Saudi Ministry expects to issue up 6 million Umrah visas for the period between December 2012 to the end of Ramadan. Four million Umrah visas covering visitors from 70 countries were issued until May 2013 with 3,145,506 pilgrims having performed Umrah (Mohammed, 2013).

In general, although religious based tourism is expanding there is not much information about the phenomenon, particularly pilgrimage tourism such as Umrah. Research on this thriving industry is limited, thus knowledge about this trend remains scarce.Until recently, relatively little attention has been given to the highlighted subject matter in the tourism literature due to the complex relationship between tourism and religion. Researchers are now taking an interest in studying religious tourism and the associated issues such as the service quality provided by the tour operators. In Malaysia, religious tourism is now in the limelight. This paper addresses the lack of research conducted with respect to Umrah pilgrimage. It performs an analysis of factors influencing the pre-trip information acquisition behavior of Umrah travelers as they seek to enhance their knowledge of the travel destination.

\section{Literature Review and Hypothesized Relationships}

Religious tourism is different from other forms of tourism in that it is characterized by its objectives, motivations, and destinations (Liszewski, 2000). Religious tourism is an ancient form of tourism, which originated many centuries ago. It is motivated by religious or spiritual commitment (Sharpley, 2009). Religiousness is defined as the principle of trust in a godly or incredible individual's strength and the procedure of reverence or other religious activities (Beit-Hallahmi, 1975). Human have always been interested in making their lives meaningful and the search for meaning in life involves religious travel, such as undertaking pilgrimage to their sacred places and taking part in rituals at those places, as well as participating in religious festivals, ceremony and events (Raj \& Morpeth, 2007). According to Vukonic (1998), religious tourism is one of the most unstudied areas in tourism research. There is a little information available about religious pilgrimages (Egresi et al., 2012). Attention has focused on the extent to which modern tourism practices can compare with or are distinct from traditional pilgrimage in terms of the social form and meaning (Smith, 1992).

It is important for religious tourism travel agents and tour operators to know how the religious travelers acquire their destination product knowledge. The information acquisition behavior of travelers is a frequently studied topic by tourism researchers (Vogt \& Fesenmaier, 1998). In a tourism related activity, information search can be seen as a key element in facilitating a pleasant and safe journey, which, ultimately, will enhance the quality of a trip. In addition, the consumer selection and choice of tourism is highly dependent on the information available and used by the consumer (Fodness \& Murray, 1998). Previous research showed that pre- event information acquisition behavior is uncommon, where less than one in five attendees search for tourism activities information prior to their travel; on other hands, people who search for information prior to travelling tend to be more proactive tourism consumers (Taks et al., 2009). Prior knowledge plays a critical role in determining risk perceptions and the subsequent amount and type of information sought (Sharifpour \& Walters, 2014). According to the extant tourism research, there is evidence indicating differences in the usage patterns of tourist information between cultures. Indeed, understanding the external information usage patterns of the travelers is critical for tourism destination marketers. However, the effect of the experience of a previous trip on information-usage patterns did not receive much attention from researchers of tourism (Chen \& Gursoy, 2000). Therefore, this study examines the relationship between the factors influencing the effort in information acquisition behavior to obtain product or destination knowledge in performing Umrah in Mecca.

\subsection{Destination Product Knowledge}

Destination product knowledge is considered as an important element for travelers to plan their journey (Cho \& Jang, 2008). According to Gursoy and McCleary (2004), information search is "the motivated activation of knowledge stored in memory or acquisition of information from the environment". A tourist information search can be divided into three major components: motives, determinants, and sources (Fodness \& Murray, 1997). The primary motive for an information search is to pre-plan the journey in order to enhance the quality and experience of the trip and to decrease the level of uncertainty. In terms of the determinants of an information search, this is a dimension that is based on past experience, travelling partner, and the existence of friends or relatives during the travel (Snepenger et al., 1990). In addition, the quality of information acquisition from internal or external sources are necessary for the selection of a destination and making onsite decisions, such as selecting the accommodation, transportation, types of activity, and tour package. The activity of an information 
search can be conceptualized as a dynamic process as individuals have access to different types and amount of information sources (Gursoy \& McCleary, 2004).

A direct information search is one of the ways for travelers to acquire pre-travel information. However, information acquisition is a much broader concept than a direct search. We can search for information from internal or external sources. An internal search is the knowledge retrieved from the memory, while an external search includes the information gathered from the marketplace. If internal information is sufficient to make a decision then the external search becomes unnecessary (Beatty \& Smith, 1987). Indeed, travelers who perform an internal information search often depend heavily on their existing knowledge. Factors, such as travelling style, age and nationality, are strong predictors for travelers searching for information from different sources (Gronflaten, 2009). A variety of channels in modern communication has been designed for tourists to obtain information or knowledge about their destinationbefore their travel. Sources of information include airlines, in-flight information systems, government tourist offices, state/city travel offices, friends and relatives, travel agencies, travel guides, tour companies, corporate travel departments, newspapers/magazines, and television/radio.

\subsubsection{Effort of Information Acquisition}

Effort in information acquisitions is engaged when the consumer has a strong motivation factor (Awasthy et al., 2012) and is based on the perceived task complexity in the decision making process. Consumers will seek information based on the complexity of the decision making situation (Hu et al., 2007). Consumers usually strive for a level of certainty in their judgment, and, thus, adjust their efforts for information search with the level of motivation. The information acquisition effort can be based on three major factors-motives, determinants, and sources (Moutinho, 1987). The primary motive of travel planning is to enhance the quality of the travel. In term of the determinants, travel party composition which is the presence of friends or relatives, past experience, and the degree of novelty associated with the destination play an important role in the effort of information acquisition (Snepenger et al., 1990). Finally, is the availability of high quality and reliable external and internal information sources. According to Fodness and Murray (1998), travelers do not depend solely on a single source when searching for pre-trip information. The effort expended on an information search is dependent on the perceptual effects based on categories of information which are the information availability, information that is exposed to tourists and the amount of information retained by the tourists (Moutinho et al., 2011). There are several types of external sources of information, which are heavily based on the type of trip, distance travelled, and cost of travel (Fodness \& Murray, 1997) and the composition of the travel party (Snepenger et al., 1990). The extent of the search for external information depends on the extent of prior product knowledge (Moutinho et al., 2011; Sharifpour \& Walters, 2014). Thus, based on this, the following hypothesis is proposed:

H1: Destination product knowledge is positively influenced by the effort of information acquisition.

\subsubsection{Purpose of Religious Travel}

People travel for various reasons, such as for recreation, tourism, religiouspilgrimages, mission trips andbusiness travel. One of the general reasons for travelling is to participate in activities, which, in turn, provide a sense of well-being (Cantor \& Sanderson, 1999). In addition, tourists tend to seek for the expectation of the benefits gain from the travel (Moutinho et al., 2011) and the optimal arousal which bring them the satisfaction of tourism. The motives of tourists change according to times and reflect the social activities in a community. In religious based tourism, religious visit to holy places can strengthen and ensure a person's religious certainty and their personal experience. Religious travel is about the purchase of an experience, such as an emotional, intellectual, spiritual or physical experience. According Ambrož and Ovsenik (2011), spiritual travelling is an effective way of finding one's true self. Hence, the traveler will put much more effort in their search for information when they are fully motivated to experience a deeper spiritual state of holy pilgrimage. Many major tourism spots have developed largely because of their connection to sacred people, sacred places, or spiritual events. At the highest level of motivation, the experience of pilgrimage itself would bring self-actualization. Umrah in Mecca is said to fulfil the unity of the soul, spirit and heart. It helps one to return to the purified state of a person, reflecting the Holy Spirit, nature and presence of God in creation (Ilsan, October 28, 2011). A strong religious sense is the main influential factor for exerting effort in searching for pre-trip information. Thus, the following hypothesis is proposed:

$\mathrm{H} 2$ : Effort in information acquisition is positively influenced by the purpose of travelling. 


\subsubsection{Quality of Information}

Credibility and the trustworthiness of sources of information are critical determinants on how individuals perceive, interpret, and respond to information (Grewal et al., 1994). According to Wong and McKercher (2011) the quality of information may be affected by the way information is provided, by what information is transmitted, the service delivery and the process of interaction. For example, source credibility has a significant effect on the individuals' response to information. The degree of effort being exerted in the information acquisition process is dependent on prior knowledge. The information acquisition process will stop when the information acquired reaches a satisfactory level rather than optimal results. Concisely, people who have collected an adequate amount of information will probably not continue to search for additional information. The key points for information sources are that they must be easily retrievable, easy to understand, credible, reliable and sufficient (Lee et al., 2002) for pre-trip planning and decision making. Quality information has to be accurate, concise, updated and has an objective focus. Hence, the amount of effort exerted for information acquisition is dependent on the quality of information and will positively influence the information acquisition effort by the travelers. Thus, the following hypothesis is proposed:

H3: Effort exerted for information acquisition is positively influenced by the quality of information on Umrah.

\subsubsection{Past Experience}

Past experience is one of the important sources of internal information and is used as the basis for planning a repeat visit to a destination. If the memory of the experience is not sufficient for decision-making, search activities will extend to the external environment (Fodness \& Murray, 1997). Consumers can gain product knowledge from their previous experience with the product, the experience of others, and by means of visual, verbal, and sensory stimuli, such as advertisements, newspaper/magazine articles, and television programs (Vogt \& Fesenmaier, 1998). The previous visits construct is proposed to positively influence the familiarity and expertise construct. Tourists who have been to the destination previously are likely to have more familiarity and expertise about the destination than those who have never been there and past experience impacts the acquisition of information from external sources (Kerstetter \& Cho, 2004). Previous study argued that people who have past experience can easily access to the related information, thereby reducing their felt search cost; on the other hands, people with low experience will be less motivated to search for travel information (Jensen, 2012). According to the Experience Use History (EUH) theory, previous involvement in activities may be utilized as an indicator of the amount and type of information upon which a person can draw to make decisions with regards to the activities (Chen \& Gursoy, 2000). Thus, based on this, the following hypothesis is proposed:

H4: Effort exerted for information acquisition is positively influenced by a traveler's past experience.

\subsubsection{Travel Companion}

A traveler's companion can determine the effort of information search behavior. Snepenger et al. (1990) identified four categories of variable that have been found to affect the information search - travelling party composition, the presence of friends or relatives at the destination, past experience, and the degree of novelty associated with the destination. Youth often travel with their parents or with their parents' permission to travel with their friends, by themselves, or following a tour group (Pizam et al., 2004). However, when people grow older, they are more likely to travel without their friends and relatives (Han et al., 2010). In addition, independent travelers pay more attention to the travel partner's needs, and the same applies to repeat visitors as people tend to seek familiarity when travelling to a new destination; on the other hands, repeat visitors love to share their previous experiences with their travel partner and try something new with their partners (Wong \& Liu, 2011). The following hypothesis is proposed:

H5: Effort exerted for information acquisition is positively influenced by the traveler's companion.

\section{Methodology}

The survey method was used to investigate the pre-trip information search behavior and preparation for religious tourism to Mecca to perform Umrah. The data were collected using a self-administered questionnaire. Six constructs were measured in this study and all items were operationalized using a five-point Likert scale and the dependent variable which is the destination product knowledge is measured with a seven-point Likert scales. The items used in the questionnaire were adopted and modified from the previous research. The factors used in the final model were purpose of travel (Ambrož \& Ovsenik, 2011), quality of information (Kerstetter \& Cho, 2004; Lee et al., 2002), past experience (Huang \& Hsu, 2009), travel companion (Pizam et al., 2004), effort of info acquisition (Hu et al., 2007; Awasthy et al., 2012) and destination product knowledge (Hu et al., 2007; Awasthy et al., 2012). 
The questionnaires were distributed to 250 respondents using purposive sampling methods in the Kelang Valley area, Ipoh, Penang and Johor Bharu in Malaysia. The final useable sample consisted of 198 Muslim participants who were aged over 18 years old, and who travelled to Mecca to perform Umrah in fulfilling their religious obligations. The partial least squares (PLS) structural equation methodology was used to develop the model showing the relationship between the predictors and product knowledge, as well as present the religious destination knowledge.

\section{Results and Discussion}

Out of the 198 respondents, $63.6 \%$ are female and $36.4 \%$ are male. The age ranges of the respondents are $20-24$ (49.5\%), 25-29 (10.9\%), 30-34 (4.0\%), 35-39 (7.9\%) and others are above forty years old. Only $31.7 \%$ of the respondents are married while $63.4 \%$ are single and the balance $(5.0 \%)$ are divorced or widowed. With respect to educational background, the majority of the respondents are bachelor-degree holders (40.6\%), followed by diploma or certificate holders $(28.7 \%)$, master's degree holders $(15.8 \%)$, high school level respondents $(5.9 \%)$ and doctoral degree holders $(8.9 \%)$. Most of the respondents are students $(54.5 \%)$, followed by respondents who work in the government sector $(22.8 \%)$, private sector $(15.8 \%)$ and respondents who run their own business $(6.9 \%)$.

Table 1. Respondents profile

\begin{tabular}{|c|c|c|c|}
\hline & & Frequency & Per cent \\
\hline \multirow{2}{*}{ Gender } & Male & 72 & 36.4 \\
\hline & Female & 126 & 63.6 \\
\hline \multirow{8}{*}{ Age } & Below 19 years old & 5 & 2.5 \\
\hline & 20-24 years old & 8 & 4.0 \\
\hline & 25-29 years old & 6 & 3.0 \\
\hline & $30-34$ years old & 12 & 6.1 \\
\hline & $35-39$ years old & 33 & 16.7 \\
\hline & $40-44$ years old & 25 & 12.6 \\
\hline & $45-49$ years old & 38 & 19.2 \\
\hline & Above 50 years old & 71 & 35.9 \\
\hline \multirow{3}{*}{ Marital status } & Single & 35 & 17.7 \\
\hline & Married & 151 & 76.3 \\
\hline & Divorced & 12 & 6.1 \\
\hline \multirow{4}{*}{ Occupation } & Government sector & 117 & 59.1 \\
\hline & Private sector & 38 & 19.2 \\
\hline & Own business & 13 & 6.6 \\
\hline & Others & 30 & 15.2 \\
\hline \multirow{4}{*}{ Education } & SPM (High School Certificate) & 24 & 12.1 \\
\hline & STPM/Diploma/Matrices & 32 & 16.2 \\
\hline & Degree & 87 & 43.9 \\
\hline & Masters & 33 & 16.7 \\
\hline \multirow{9}{*}{$\begin{array}{l}\text { Monthly Income } \\
\text { (in Ringgit Malaysia (RM)) }\end{array}$} & $\mathrm{PhD}$ & 11 & 5.6 \\
\hline & Others & 11 & 5.6 \\
\hline & Below RM2000.00 & 23 & 11.6 \\
\hline & RM2000.00-RM3499.99 & 31 & 15.7 \\
\hline & RM3500.00-RM4999.99 & 57 & 28.8 \\
\hline & RM5000.00-RM6499.99 & 45 & 22.7 \\
\hline & RM6500.00-RM7999.99 & 21 & 10.6 \\
\hline & RM8000.00-RM9499.99 & 15 & 7.6 \\
\hline & Above RM10000.00 & 6 & 3.0 \\
\hline
\end{tabular}

Table 2 lists 13 sources of information used by the respondents. Friends and relatives, and personal experience with means scores of 3.86 and 3.20, respectively, are the most important sources of internal information for all the respondents. Travel agent, guidebook and brochure with mean scores of 3.57, 3.47 and 3.18, respectively, are the most used source of external information. Email and direct mail are the least preferred sources of information used to find information about religious tourism. 
Table 2. Information sources used for Umrah travelers

\begin{tabular}{|c|c|c|c|c|c|}
\hline & $\mathrm{N}$ & Minimum & Maximum & Mean & Std. Deviation \\
\hline Brochures & 198 & 1 & 5 & 3.18 & 1.324 \\
\hline Guide Books & 198 & 1 & 5 & 3.47 & 1.377 \\
\hline Magazines & 198 & 1 & 5 & 2.98 & 1.173 \\
\hline Newspapers & 198 & 1 & 5 & 2.94 & 1.227 \\
\hline In-Flight Info & 198 & 1 & 5 & 2.71 & 1.220 \\
\hline Advertisement & 198 & 1 & 5 & 2.99 & 1.310 \\
\hline Social Media & 198 & 1 & 5 & 2.80 & 1.335 \\
\hline Email & 198 & 1 & 5 & 2.37 & 1.171 \\
\hline Direct Mail & 198 & 1 & 5 & 2.45 & 1.142 \\
\hline Travel Agents/tour operators & 198 & 1 & 5 & 3.57 & 1.386 \\
\hline Friends and Relatives & 198 & 1 & 5 & 3.86 & 1.285 \\
\hline Personal Experience & 198 & 1 & 5 & 3.20 & 1.438 \\
\hline Airlines & 198 & 1 & 5 & 2.66 & 1.251 \\
\hline Valid N (listwise) & 198 & & & & \\
\hline
\end{tabular}

\subsection{Measurement Model}

The measurement model with reflective indicator was modelled using Smart PLS. The measurement model was evaluated by examining individual item reliability, internal consistency or construct reliability, average variance extracted analysis, and discriminant validity. A measurement model has satisfactory internal consistency reliability when the composite reliability (CR) of each construct exceeds the threshold value of 0.7. Table 3 shows that the $\mathrm{CR}$ of each construct for this study ranges from 0.901 to 0.958 and that this is above the recommended threshold value of 0.7 . Thus, the results indicate that the items used to represent the constructs have satisfactory internal consistency reliability. Indicators of the reliability of the measurement model are measured by examining the items loadings. A measurement model is said to have a satisfactory indicator reliability when the loading of each item is at least 0.7 and is significant at least at the level of 0.05 . Based on the analysis, all items in the measurement model exhibited loadings exceeding 0.7 . All items are significant at the 0.01 level. Based on the results, all items used for this study have demonstrated satisfactory indicator reliability.

Table 3. Overview validity and reliability of the model

\begin{tabular}{|c|c|c|c|c|c|}
\hline Construct & Item & Loading & AVE & $\mathrm{CR}$ & $\alpha$ \\
\hline \multirow{5}{*}{$\begin{array}{l}\text { Purpose of } \\
\text { Travel }\end{array}$} & PT1: ... to find my inner self. & 0.916 & 0.819 & 0.958 & 0.944 \\
\hline & PT2: ... to help understand myself better. & 0.909 & & & \\
\hline & PT3: ... to be at peace with myself. & 0.921 & & & \\
\hline & PT4: ... to experience calmness. & 0.931 & & & \\
\hline & PT5: ... to gain a sense of renewal. & 0.846 & & & \\
\hline \multirow{5}{*}{$\begin{array}{l}\text { Effort of } \\
\text { Info } \\
\text { Acquisition }\end{array}$} & IA1: ... don't give up searching until I have gathered all the possible information. & 0.903 & 0.740 & 0.934 & 0.911 \\
\hline & IA2: ... don't give up searching until I have exhausted all possible sources. & 0.894 & & & \\
\hline & IA3: ... collect information from different sources even if it is difficult to access. & 0.879 & & & \\
\hline & $\begin{array}{l}\text { IA } 4: \ldots \text { a lot of effort to obtain additional information before deciding upon which } \\
\text { Umrah package to use. }\end{array}$ & 0.830 & & & \\
\hline & IA5: ... acquire the maximum amount of information even if it delays my travelling. & 0.788 & & & \\
\hline \multirow{5}{*}{$\begin{array}{l}\text { Past } \\
\text { Experience }\end{array}$} & PE1: ... people in the destination area were friendly. & 0.711 & 0.694 & 0.918 & 0.888 \\
\hline & PE2: ... built friendship(s) through the travelling experience. & 0.789 & & & \\
\hline & PE3: ... the travelling was spiritually challenging. & 0.903 & & & \\
\hline & PE4: ... the travelling was physically challenging. & 0.895 & & & \\
\hline & PE5: ... the activities during the pilgrim require many skills. & 0.851 & & & \\
\hline \multirow{6}{*}{$\begin{array}{l}\text { Quality of } \\
\text { Information }\end{array}$} & QI1: ... is easily retrievable. & 0.926 & 0.841 & 0.970 & 0.962 \\
\hline & Q12: ... is quickly accessible when needed. & 0.908 & & & \\
\hline & QI3: ... is sufficient for my needs. & 0.908 & & & \\
\hline & QI4: ... is easy to understand. & 0.918 & & & \\
\hline & QI5: ... is credible. & 0.914 & & & \\
\hline & QI6: ... is reliable. & 0.930 & & & \\
\hline \multirow{4}{*}{$\begin{array}{l}\text { Travel } \\
\text { Companion }\end{array}$} & TC1: ... travel with a person or people who are important to me. & 0.844 & 0.694 & 0.901 & 0.853 \\
\hline & TC2: ...travel with my friends. & 0.824 & & & \\
\hline & TC3: ...travel with my family and relatives. & 0.876 & & & \\
\hline & TC4: ...travel with a tour group. & 0.787 & & & \\
\hline
\end{tabular}




\begin{tabular}{|c|c|c|c|c|c|}
\hline \multirow{6}{*}{$\begin{array}{l}\text { Destination } \\
\text { Product } \\
\text { Knowledge }\end{array}$} & DPK1: ... knowledgeable about the places I visiting. & 0.790 & 0.727 & 0.941 & 0.925 \\
\hline & DPK2: ... more informed about the places visiting compared to others. & 0.800 & & & \\
\hline & DPK3: ... know about all the features on the tour package. & 0.881 & & & \\
\hline & DPK4: ... know the importance of the different features of the tour packages. & 0.860 & & & \\
\hline & DPK5: ... know how to compare the features of the different tour packages. & 0.892 & & & \\
\hline & $\begin{array}{l}\text { DPK6: ... satisfied with the level of knowledge that I have about the places that I } \\
\text { visited. }\end{array}$ & 0.886 & & & \\
\hline
\end{tabular}

In this study, the discriminant validity of the measurement model is assessed using Fornell and Larcker's(1981) criterion. The results in Table 4 show that a measurement model has discriminant validity when the square root of the AVE exceeds the correlations between the measure and all the other measures, and the indicators' loadings are higher against their respective constructs compared to the other constructs. Hence, the results confirmed that Fornell and Larcker's criterion is met.

Table 4. Discriminant analysis

\begin{tabular}{|c|c|c|c|c|c|c|c|}
\hline & AVE & $\begin{array}{c}\text { Effort of Info } \\
\text { Acquisition }\end{array}$ & $\begin{array}{c}\text { Past } \\
\text { Experience }\end{array}$ & $\begin{array}{c}\text { Destination } \\
\text { Product } \\
\text { Knowledge }\end{array}$ & $\begin{array}{c}\text { Purpose of } \\
\text { Travel }\end{array}$ & $\begin{array}{l}\text { Quality of } \\
\text { Information }\end{array}$ & $\begin{array}{c}\text { Travel } \\
\text { Companion }\end{array}$ \\
\hline $\begin{array}{l}\text { Effort of } \\
\text { Information } \\
\text { Acquisition }\end{array}$ & 0.740 & 0.860 & & & & & \\
\hline $\begin{array}{l}\text { Past Experience } \\
\text { Destination }\end{array}$ & 0.694 & 0.698 & 0.833 & & & & \\
\hline $\begin{array}{l}\text { Product } \\
\text { Knowledge }\end{array}$ & 0.727 & 0.588 & 0.659 & 0.853 & & & \\
\hline Purpose of Travel & 0.819 & 0.609 & 0.655 & 0.524 & 0.905 & & \\
\hline $\begin{array}{l}\text { Quality of } \\
\text { Information }\end{array}$ & 0.841 & 0.684 & 0.799 & 0.692 & 0.726 & 0.917 & \\
\hline $\begin{array}{l}\text { Travel } \\
\text { Companion }\end{array}$ & 0.694 & 0.637 & 0.706 & 0.695 & 0.684 & 0.794 & 0.833 \\
\hline
\end{tabular}

Note. Values in the diagonal (bolded) are the square root of the AVE while the off-diagonals are the inter-construct correlations.

\subsubsection{Path Coefficients and Hypotheses Testing}

A major emphasis in PLS analysis concerns the variance explained as well as establishing the significance of all path estimates. Specifically, the predictive power of the structural model is assessed by the $\mathrm{R}^{2}$ values of the endogenous constructs. Figure 1 and Table 5 present the results of the model and the path analysis to test the hypotheses. Based on the path coefficient and t-test results for the five hypotheses, only four hypotheses are supported. The hypothesis related to travel companion is not supported. The results show that travelling purpose and quality of information positively influences the effort exerted for religious information acquisition at a significant level of $\mathrm{p}<0.05$. However, past experience positively influences the effort exerted for religious information acquisition at a significant level of $\mathrm{p}<0.01$.

The results of the $\mathrm{R}^{2}$ value is 0.552 and 0.345 , which suggests that $55.2 \%$ of the variance in effort of information acquisition can be explained by the purpose of travelling, quality of information and past experience on religious travelling, and $34.5 \%$ of the variance in destination product knowledge can be explained by the effort of information acquisition. This means that travelers are knowledgeable about the places they visited, more informed about the places that they visited compared to others, know about all the features and differences in the tour packages, and, finally, are satisfied with the level of knowledge that they have about the places they visited. 


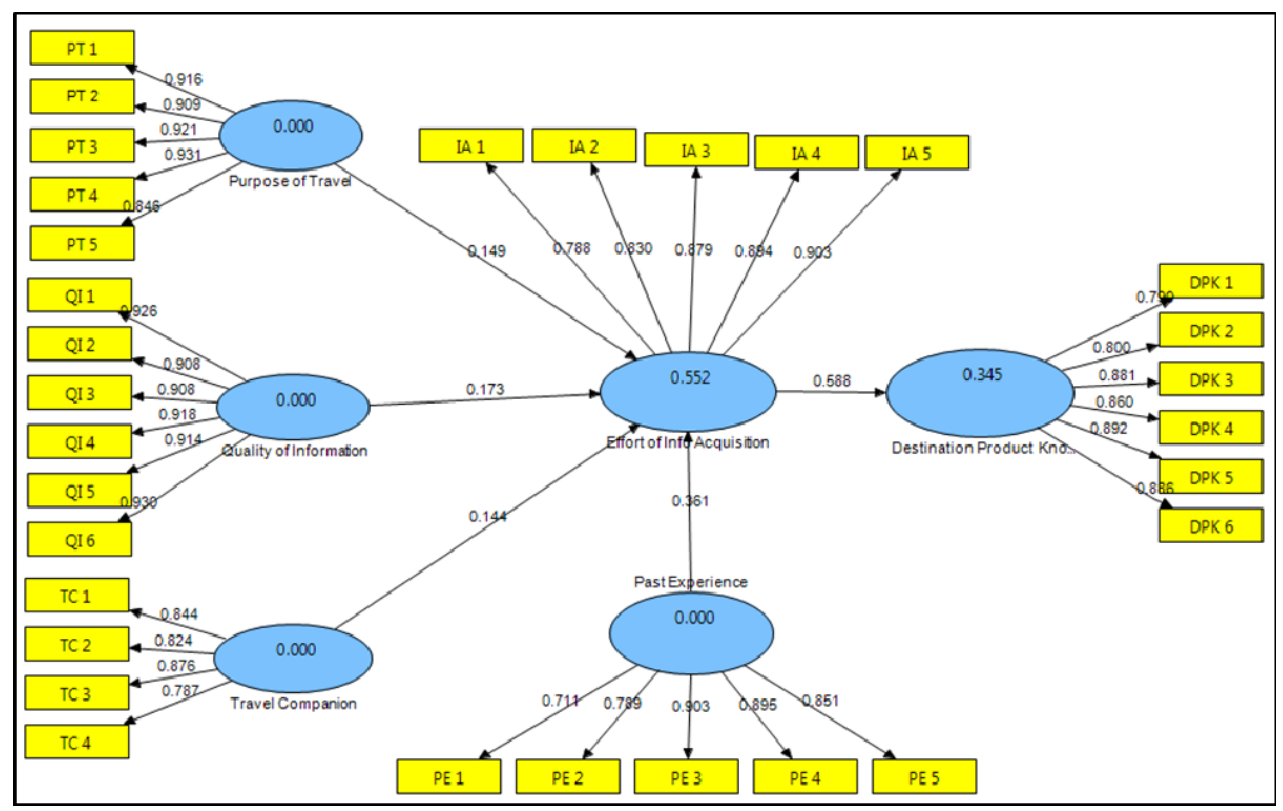

Figure 1. Measurement model

Table 5. Path coefficient

\begin{tabular}{|c|c|c|c|c|c|}
\hline Hypothesis & Path Relationship & $\mathrm{B}$ & Std. Error & t-value & Decision \\
\hline H1 & Effort of Info Acquisition --> Destination Product Knowledge & 0.588 & 0.057 & 10.272 & Supported \\
\hline $\mathrm{H} 2$ & Purpose of Travel --> Effort of Info Acquisition & 0.149 & 0.084 & 1.767 & Supported \\
\hline $\mathrm{H} 3$ & Quality of Information- -> Effort of Info Acquisition & 0.173 & 0.095 & 1.814 & Supported \\
\hline $\mathrm{H} 4$ & Past Experience --> Effort of Info Acquisition & 0.361 & 0.079 & 4.567 & Supported \\
\hline H5 & Travel Companion --> Effort of Info Acquisition & 0.144 & 0.082 & 1.749 & Supported \\
\hline
\end{tabular}

Note. if the t-value is greater than $1.645(* \mathrm{p}<0.05), 2.33(* * \mathrm{p}<0.01)$.

Understanding the consumer's information search process is critical for both the tour operators and travel agents strategic decision areas, such as communications planning, new product introduction and customer relationship management. Based on the descriptive analysis, it shows that Umrah travelers choose friends and relatives, and personal experience as two of the most important sources of internal information. This is because information provided by relatives and friends is the most trusted information compared to other external information sources, such as email and direct mail. Both of which received the lowest score and are the least preferred information source listed for Umrah travelers. This finding is consistent with previous literature (Beatty \& Smith, 1987; Fodness \& Murray, 1999; Moutinho et al., 2011), who stated that when the internal search is enough for the information demanded, it is unnecessary to undertake an external information search. Indeed, travelers who perform an information search often depend heavily on the adequacy or quality of their existing knowledge. Travel agent, guidebook and brochure are the most useful sources for external information search. Email and direct mail are the least preferred sources used to find information about religious tourism. For the external source, the Umrah travelers rely on information sources, such as travel agent, guidebook and brochure. These types of information source are believed to give detailed information about the Umrah and Ziarah tour packages for Mecca and Madinah. The criteria of the quality of these information sources must be easily retrievable, quickly accessible, easy to understand, credible, reliable and sufficient.

The finding from the measurement model shows all hypotheses proposed in the study were supported by the data. The effort of information acquisition behavior can be explained by the purpose of travelling, quality of information and past experience of religious travelling. All these factors significantly influence the information acquisition behavior that later makes the travelers more knowledgeable and more informed about their destination, and more aware of the importance of the different features of the chosen Umrah tour package compared to others. This finding is in line and supported by the previous research that information acquisition is necessary for selecting a destination and for on-site decisions such as selecting accommodations, transportation, tours and more importantly purchase decision (Snepenger et al., 1990; Awasthy et al., 2012) 
The research finding shows that travelers travel to the holy places in Mecca to find their inner self, understand and be at peace with themselves, to experience calmness and to gain a sense of renewal. This finding is supported by previous research that religious based tourism travelers travel for spiritual renewal (Vukonic, 1996) and connect with something greater than themselves at those locations (Timothy \& Olsen, 2006). Past experience that can be considered as prior knowledge has the highest t-value that influences the effort of information acquisition. Evidence from past literature contradicts the finding that prior knowledge influences the information acquisition behavior (Gursoy \& Chen, 2000, Kerstetter \& Cho, 2004). Some other researchers concluded that there is a negative relationship between prior knowledge and external search (Coupey et al., 1998; Fodness \& Murray, 1998). However, in this study, past experience has a positive and significant relationship with the effort of information acquisition behavior. Last but not least, the travel companion also will influence the amount of effort put in the information acquisition which supported by previous literature (Snepenger et al., 1990).

\section{Conclusion, Implications, and Limitations}

This study contributes some meaningful insight for religious tourism literature, marketers and practitioners. The finding will provide new knowledge to marketing management on how to best utilize an understanding the information acquisition behavior of Umrah travelers. It is important for marketers to have an overall picture of how religious travelers acquire information. In Malaysia, gaining an understanding of how Muslim tourists acquire knowledge in religious tourism is important for marketing management decisions, as Muslims comprise the largest religious group. The findings have direct implications for tour operators and travel agents, as they can help travel agents and marketers develop target-marketing communications more effectively. Like most industries, being a part of the tourism industry requires the tour operators and travel agents to have industry specific knowledge to create and operate a successful business. Effective communication campaigns and service delivery during the process of information acquisition can influence consumers' purchase decision. In addition, the knowledge concerning how Muslims acquire information for their religious trip is important for practitioners to develop effective target-marketing communication to influence the buying decisions of consumers concerning their religious trip.

The religious tourism provider also can make basic market segmentation to enable focus in positioning and media selection. From the descriptive analysis, the findings show that travelers seek information from friends and relatives, and rely on personal experience for their internal source of information, whereas the guidebook and brochure, and travel agent are the most used source of external information. Based on these findings, the tour operators and travel agents should use these information sources to promote their tour packages that are related to religious tourism. Similarly, for the practitioners, they should leverage these sources of information to promote their religious tourism related packages. For example, in terms of the quality of information, the travel agents and tour operators must ensure that information concerning the Umrah packages is easily accessible and retrievable when required. In addition, the information must be sufficient, credible, reliable and easy to understand. These are the important criteria that an Umrah traveler considers with respect to the quality of information.

In conclusion, understanding the factors influencing travelers who are searching for travelling information can assist both the managers and marketers to develop marketing communications more effectively. The model is developed to help religious tourism marketers, managers, and researchers to comprehend the information search behavior of Umrah travelers. In addition, for information accessibility by their customers, convenience and accuracy of information is important. Factors, such as sufficiency, credibility, reliability and clarity should be of the highest quality because Umrah travelers consider these criteria to be important for quality of information. Although the results underlined significant findings, there are also limitations to this study. The data collection was collected by a purposive convenience sampling method in Malaysia, thus, the results may not be suited to Muslim travelers from other countries.

\section{Acknowledgements}

The authors would like to thank UniversitiSains Malaysia for funding this research under the Research University grant no. 1001/PMGT/816211.

\section{References}

Ambrož, M., \& Ovsenik, R. (2011). Tourist Origin and Spiritual Motives. Management, 16, 71-86.

Awasthy, D., Banerjee, A., \& Banerjee, B. (2012). Understanding The Role of Prior Product Knowledge to Information Search: An Application of Process Theory To The Indian Market. Asia Pacific Journal of Marketing And Logistics, 24, 257-287. http://dx.doi.org/10.1108/13555851211218057 
Beatty, S. E., \& Smith, S. M. (1987). External Search Effort: An Investigation Across Several Product Categories. Journal Of Consumer Research, 14, 83-95. http://dx.doi.org/10.1086/209095

Beit-Hallahmi, B. (1975). The Social Psychology Of Religion. London, Routledge \& Kegan Paul.

Bremer, T. S. (2005). Tourism and Religion. Encyclopedia Of Religion, Detroit: Macmillian Reference Usa. Thomas Gale (pp. 9260-9264).

Cantor, N., \& Sanderson, C. A. (1999). 12 Life Task Participation and Well-Being: The Importance of Taking Part In Daily Life. Well-Being: Foundations Of Hedonic Psychology, 230.

Chen, J. S., \& Gursoy, D. (2000). Cross-Cultural Comparison of The Information Sources Used by First-Time and Repeat Travelers and Its Marketing Implications. International Journal Of Hospitality Management, 19, 191-203. http://dx.doi.org/10.1016/S0278-4319(00)00013-X

Cho, M. H., \& Jang, S. (2008). Information Value Structure For Vacation Travel. Journal of Travel Research, 47 , 72-83. http://dx.doi.org/10.1177/0047287507312422

Coupey, E., Irwin, R., \& Payne, J. (1998). Product Category Familiarity and Preference Construction. Journal of Consumer Research, 24, 459-468. http://dx.doi.org/10.1086/209521

Egresi, I., Bayram, B., \& Kara, F. (2012). Tourism at Religious Sites: A Case From Mardin, Turkey. Geographica Timisiensis, 21, 5-15.

Fodness, D., \& Murray, B. (1997). Tourist Information Search. Annals Of Tourism Research, 24, 503-523. http://dx.doi.org/10.1016/S0160-7383(97)00009-1

Fodness, D., \& Murray, B. (1998). A Typology of Tourist Information Search Strategies. Journal of Travel Research, 37, 108-119. http://dx.doi.org/10.1177/004728759803700202

Fodness, D., \& Murray, B. (1999). A Model of Tourist Information Search Behavior. Journal of Travel Research, 37, 220-230. http://dx.doi.org/10.1177/004728759903700302

Fornell, C., \& Larcker, D. F. (1981). Evaluating Structural Equation Models With Unobservable Variables and Measurement Error. Journal of Marketing Research (Jmr), 18, 39-50. http://dx.doi.org/10.2307/3151312

Grewal, D., Gotlieb, J., \& Marmorstein, H. (1994). The Moderating Effects of Message Framing and Source Credibility On The Price-Perceived Risk Relationship. Journal of Consumer Research, 21, 145-153. http://dx.doi.org/10.1086/209388

Gronflaten, O. (2009). The Tourist Information Matrix-Differentiating Between Sources and Channels In The Assessment of Travellers' Information Search. Scandinavian Journal of Hospitality And Tourism, 9, 39-64. http://dx.doi.org/10.1080/15022250902761280

Gursoy, D., \& Chen, J. (2000). Competitive Analysis of Cross Cultural Information Search Behavior. Tourism Management, 21, 583-590. http://dx.doi.org/10.1016/S0261-5177(00)00005-4

Gursoy, D., \& Mccleary, K. W. (2004). An Integrative Model of Tourists Information Search Behaviour. Annals Of Tourism Research, 31, 353-373. http://dx.doi.org/10.1016/j.annals.2003.12.004

Han, P., Balaban, V., \& Marano, C. (2010). Travel Characteristics and Risk-Taking Attitudes In Youths Traveling To Nonindustrialized Countries. Journal of Travel Medicine, 17, 316-321. http://dx.doi.org/10.1111/j.1708-8305.2010.00444.x

Haq, F., \& Wong, H. Y. (2010). Is Spiritual Tourism A New Strategy For Marketing Islam? Journal Of Islamic Marketing, 1, 136-148. http://dx.doi.org/10.1108/17590831011055879

Hu, J., Huhmann, B. A., \& Hyman, M. R. (2007). The Relationship Between Task Complexity and Information Search: The Role of Self-Efficacy. Psychology \& Marketing, 24, 253-270. http://dx.doi.org/10.1002/mar.20160

Huang, S. S., \& Hsu, C. H. (2009). Effects of Travel Motivation, Past Experience, Perceived Constraint, and Attitude on Revisit Intention. Journal Of Travel Research. http://dx.doi.org/10.1177/0047287508328793

Ilsan, A. (2011, October 28). Why Do Muslims Go To Hajj In Mecca? Retrieved from http://Www.Ihsanalexander.Com/Blog/Why-Do-Muslims-Go-To-Hajj-In-Mecca/

Jensen, J. M. (2012). Shopping Orientation and Online Travel Shopping: The Role of Travel Experience. International Journal Of Tourism Research, 14, 56-70. http://dx.doi.org/10.1002/jtr.835 
Kerstetter, D., \& Cho, M.-H. (2004). Prior Knowledge, Credibility and Information Search. Annals Of Tourism Research, 31, 961-985. http://dx.doi.org/10.1016/j.annals.2004.04.002

Lee, Y. W., Strong, D. M., Kahn, B. K., \& Wang, R. Y. (2002). Aimq: A Methodology For Information Quality Assessment. Information \& Management, 40, 133-146. http://dx.doi.org/10.1016/S0378-7206(02)00043-5

Liszewski, A. (2000). Pilgrimages Or Religious Tourism? Peregrinus Cracoviensis, Krakow: Institute Of Geography, Jagiellonian University.

Mohammed, I. (2013). 4 Million Visas Issued For Umrah This Year. Retrieved from http://Www.Arabnews.Com/News/452027

Moutinho, L. (1987). Consumer Behavior In Tourism. European. Journal Of Marketing, 21, 44.

Moutinho, L., Ballantyne, R., \& Rate, S. (2011). Consumer Behaviour In Tourism. Strategic Management In Tourism, 2, 83-126.

Pizam, A., Jeong, G. H., Reichel, A., Van Boemmel, H., Lusson, J. M., Steynberg, L., ... Montmany, N. (2004). The Relationship Between Risk-Taking, Sensation-Seeking, And The Tourist Behavior of Young Adults: A Cross-Cultural Study. Journal Of Travel Research, 42, 251-260. http://dx.doi.org/10.1177/0047287503258837

Raj, R., \& Morpeth, N. D. (2007). Religious Tourism and Pilgrimage Management: An International Perspective. Cabi. http://dx.doi.org/10.1079/9781845932251.0000

Sharifpour, M., \& Walters, G. (2014). The Interplay Between Prior Knowledge, Perceived Risk and The Tourism Consumer Decision Process: A Conceptual Framework. The Marketing Review, 14, 279-296. http://dx.doi.org/10.1362/146934714X14024779061956

Sharpley, R. (2009). Tourism, Religion, and Spirituality. In Jamal, T. \& Robinson, M. (Eds.), The Sage Handbook Of Tourism Studies. London: Sage. http://dx.doi.org/10.4135/9780857021076.n14

Simon Wong, C. K., \& Gladys Liu, F. C. (2011). A Study of Pre-Trip Use of Travel Guidebooks by Leisure Travelers. Tourism Management, 32, 616-628. http://dx.doi.org/10.1016/j.tourman.2010.05.013

Smith, V. L. (1992). Introduction: The Quest In Guest. Annals Of Tourism Research, 19, 1-17. http://dx.doi.org/10.1016/0160-7383(92)90103-V

Snepenger, D. J., Meged, K., Snelling, M., \& Worrall, K. (1990). Information Search Strategies by Destination-Naive Tourists. Journal Of Travel Research, 29, 13-19. http://dx.doi.org/10.1177/004728759002900104

Taks, M., Chalip, L., Green, B. C., Kesenne, S., \& Martyn, S. (2009). Factors Affecting Repeat Visitation and Flow-On Tourism as Sources of Event Strategy Sustainability. Journal of Sport \& Tourism, 14, 121-142. http://dx.doi.org/10.1080/14775080902965066

Timothy, D. J., \& Olsen, D. H. (2006). Tourism And Religious Journeys. In Timothy, D. J. \& Olsen, D. H. (Eds.), Tourism, Religion And Spiritual Journeys. London: Routledge.

Vogt, C. A., \& Fesenmaier, D. R. (1998). Expanding the Functional Information Search. Annals of Tourism Research, 25, 551-578. http://dx.doi.org/10.1016/S0160-7383(98)00010-3

Vukonic, B. (1996). Tourism and Religion. In JAFARI, J. (Ed.), Tourism Social Science Series. Oxford, UK: Pergamon Press.

Vukonic, B. (1998). Religious Tourism: Economic Value or An Empty Box? Zagreb International Review of Economics and Business, 1, 83-94.

Ward, D. (2012). December 18. Pilgrims' Progress: Religious Tourism is Growing Despite a Slow Economy. Deseret News.

Wong, C. U., \& Mckercher, B. (2011). Tourist Information Center Staff as Knowledge Brokers: the Case of Macau. Annals of Tourism Research, 38, 481-498. http://dx.doi.org/10.1016/j.annals.2010.10.003

\section{Copyrights}

Copyright for this article is retained by the author(s), with first publication rights granted to the journal.

This is an open-access article distributed under the terms and conditions of the Creative Commons Attribution license (http://creativecommons.org/licenses/by/3.0/). 